Research Note

\title{
NOTE ON STUART HALL'S “CULTURAL IDENTITY AND DIASPORA”
}

\author{
IAN HUSSEY \\ York University. Toronto, Ontario, Canada
}

\begin{abstract}
Biographical Note
lan Hussey is a PhD Candidate in Sociology at York University. He has published in Interface: A Journal For and About Social Movements; Canadian Journal of Sociology; Canadian Journal of Globalization; Socialist Studies; and, Journal of Business Ethics.Email: ihussey@yorku.ca
\end{abstract}

\begin{abstract}
For some Marxists, issues of culture, identity and representation are secondary. In this research note, I analytically reflect on Stuart Hall's (1996) canonical essay "Cultural Identity and Diaspora," which stresses that these are significant concerns for anyone struggling for liberation. In his essay, Hall explicates two definitions of "cultural identity." The first is an essentialist identity, which emphasizes the similarities amongst a group of people. Hall argues that this definition can and does inspire feminist, anti-colonial and anti-racist art and activism, but cannot help us comprehend the trauma of colonialism. The second definition emphasizes the similarities and the differences amongst an imagined cultural group. Hall asserts that this definition is useful for understanding the trauma of colonialism because it emphasizes the historical and social contingency of identity. By using this definition in our analysis of power and normalization, we are better able to scrutinize historical and contemporary colonial relations and to struggle against them.
\end{abstract}

\section{Keywords}

cultural identity; representation; essentialism; colonialism; race

\section{Cultural Identity and the Trauma of the Colonial Experience}

Ian Hussey, York University, 23 May 2014

Socialists often say that issues of culture, identity and representation are secondary. Along with others interested in how socialism is articulated with anti-racism and anti-colonialism, however, Stuart Hall's (1996) canonical essay "Cultural Identity and Diaspora" reminds us that these are major concerns for anyone struggling for liberation. In this research note, I reflect on 
Hall's classic essay to pay tribute to the cultural studies icon, remind readers of one of his seminal contributions, and make the case for why this means that socialists ought to take culture seriously.

Hall's essay investigates and furthers a discussion on cultural identity and representation. This is occasioned by the emergence of a new cinema of the Caribbean that joins other related but different cultural practices and forms of representation in placing the black subject at their centre (110). At the same time, Hall reminds us that 'the heart has its reasons', so that this concern reflects his own trajectory as a child and youth in Jamaica who then spent his whole adult life in Britain. Cultural identity and diaspora appear simultaneously as political, scholarly and personal concerns.

Specifically, Hall explores two conceptualizations of "cultural identity." The first is an essentialist identity that emphasizes the similarities that purportedly comprise the "oneness", the underlying essence, of "a people" (111-112). It is this identity that practices of representation, such as cinema, seek to (re-)discover, excavate and enunciate. The second definition of "cultural identity" emphasizes the similarities and the differences amongst an imagined cultural group such as "The Black Triangle" of Africa, the United States, the Caribbean and the United Kingdom - who have similarities in their histories and ancestries but whose past as "a people" contains ruptures due to "the continuous 'play' of history, culture and power" $(111,112)$. Like historical materialists, Hall emphasizes that identity is contingent and not ahistorical or immutable; however, he takes ideas about identity, representation and race more seriously and is concerned with them more centrally than in many historical materialists accounts that focus more exclusively on concerns around class and class consciousness.

Hall argues that we cannot comprehend the trauma of "the" colonial experience by using the first essentialist definition but we can by using the second definition, which emphasizes historical and social contingency.

\section{The Power and Creativity of Essentialism}

Essentialist conceptualizations of identity claim there is an authentic cultural identity, a "true self", which "people with a shared history and ancestry hold in common" (111). The "oneness" this definition purports is understood to be a "stable, unchanging and continuous [frame] of reference and meaning" that reflects the general, shared cultural codes and common historical experiences of "a people" (111). Within the boundaries of this definition, the "authentic" cultural identity is understood to be hidden underneath or obfuscated by "more superficial or artificially imposed 'selves" (110-111). "Authentic" cultural identity, this shared essence, is foundational to "a people"; it is the unwavering truth that lies "beneath the shifting divisions and vicissitudes of [their] actual history" (111).

I will turn to Hall's critique of this essentialist definition, including the idea of the "oneness" of "a people" momentarily. But first it is important to note that while Hall questions the essentialist definition of "cultural identity", he cautions against neglecting or 
underestimating "the powerful and creative force" motivating the rediscovery of "hidden histories" and the content of what is "found" in these "rediscoveries" (111). He points out that the excavation of "hidden histories" has provided motivation and an organizational logic to much feminist, anti-racist and anti-colonial art and activism. In the world of art, he suggests, it is essentialist understandings of cultural identity that cinematic representations often seek to dig up, mourn the loss of and romanticize. It is this formulation that played the muse for the Negritude movement and the Pan-African political project. The essentialist understanding of cultural identity also played a motivational and organizational role in anti-colonial struggles, such as the Algerian revolution, and continues to inspire national and transnational art and activism.

Notwithstanding this "powerful and creative force", however, Hall argues that the act of "rediscovery" is ultimately "an act of imaginary reunification" $(111,112)$. Such acts "[impose] an imaginary coherence on the experience of dispersal and fragmentation, which is the history of all enforced diasporas" (112). Cinema and photographic practices achieve this "[imposition of] an imaginary coherence" amongst "the peoples of The Black Triangle", for instance, by representing or conceptualizing Africa as the centre, "the missing term", that gives meaning and coherence to a purported underlying black cultural identity $(112,111,112)$. Such representations of cultural identities of diaspora ignore the practical experiences of "ruptures and discontinuities" (112) experienced in the diaspora. But, for Hall, such representations of "imaginary reunification" are significant in beginning to heal "the rift of separation, the "loss of identity" caused by colonialism, transportation, and slavery (112). These representations are resources of identity and of resistance intended to and, in fact, strategically used to combat and to reinterpret "the fragmented and pathological ways" that dominant, Western cinema have represented colonial, post-colonial, and anti-colonial experiences (112). Yet, ultimately, such essentialist approaches become problematic, despite the ways that they give - and have given - creative and practical impetus to important anti-colonial movements.

\section{An Unaccomplished Fact}

For Hall, the authenticity and authority to which the concept of "cultural identity" can lay claim is questionable because practices of representation always implicate the positions of enunciation from which they are formulated (110). Indeed, as we have seen, Hall emphasizes that his own scholarly discourse is spoken from specific places, including his own experience as a Jamaican-born and raised youth who has spent his adulthood in the diaspora. The implication of the positionality or standpoint of the subject means that practices of representation are always enunciated in and from a particular, yet ongoing and changing context of place, time, culture and history (110). Because "all discourse is 'placed", even discourses of identity, it follows that identity is not transparent or an "accomplished fact" that cultural forms of production, such as cinema, can represent authentically and authoritatively (110). Rather, identity is itself an ongoing process of "production" that is constituted within, never outside, representation (110). We 
cannot speak for long about "one experience, one identity" with much exactness without coming to acknowledge "the ruptures and discontinuities" in the history of "a people", whether it be people of a 'voluntary' diaspora or of an imperial power forcing the dispersal and enslavement (112).

This is why Hall's second definition of "cultural identity" is so poignant: it points out that what we call "identity" is an ongoing process "of 'becoming' as well as of 'being" (112). In this way, it "belongs to the future as much as to the past" (112). Identities are not a priori; they do not transcend culture, history, time, and place (112). They are historical; they "come from somewhere"; they change in and through power relations that are temporal, placed, spatial, and situational (112). The past does not just wait idly by; rather, through social imaginings of the past, as well as material relations of the past that live on in the configurations of contemporary relations, it is active; the past transforms, and can be liberating or debilitating. This is why Hall is so apt in describing identities as "the names we give to the different ways we are positioned by, and position ourselves within, the narratives of the past" (112). And, this is why he argues that it is only by using the second definition of "cultural identity" that we can comprehensively analyze "the traumatic character of "the colonial experience" (112). It is this second position that enables an investigation of the power and normalization to which the colonial regimes "subject-ed" the colonized (112). If one adopts the essentialist definition of "cultural identity" and forecloses the possibility that identities change, then one cannot begin to comprehend, let alone recognize as such, the differences as well as the similarities among "a people" and between "different peoples" that were and are constituted in and by relations of that "fatal couplet, "power/knowledge" (112). In this light, cultural representations like those in cinema, photography and other arts are not simply 'a second-order mirror' of an essentialized identity, but productive of old and new identities. In this sense, modern black cinema is a vital part of the construction of new positionalities for those in the black diaspora.

\section{Closing Remarks}

Socialists emphasize the primacy of class in trying to understand power and to organize people. Hall would agree that class is important, but he would also question the isolation of class from other culturally significant modes of power like race, gender and sexuality. Moreover, from Foucault, he insists on the productive relation of power. If one recalls Karl Marx's anti-essentialist analysis of a class of itself and a class for itself in "The Eighteenth Brumaire", however, then Hall's approach should not be seen as 'foreign' to socialists. Rather, it should be clear that cultural issues of identity and representation have been critical to socialists for a long time, although typically centered around class cultures and not those of racialized subalterns. What Hall's work and cultural studies more generally offers us is a set of concepts and ways of thinking critically about history and people's lived conditions that take seriously issues of culture, identity and representation, where these are not understood as fixed but as historically 
contingent and social. Moreover, Hall's essay is a reminder that cultural identity has been and still is an important motivator in getting masses of people to come together around a common goal. Socialists and others struggling for liberation may find Hall's work, and cultural studies more generally, useful in thinking critically about these motivations and organizational logics that have been and continue to be significant for so many people.

\section{References}

Hall, Stuart. "Cultural Identity and Diaspora". In Contemporary Postcolonial Theory: A Reader. Padmini Mongia. (Ed.). London: Arnold, 1996: 110-121.

Marx, Karl. "The Eighteenth Brumaire of Louis Bonaparte." Available at: http://www.marxists.org/archive/marx/works/1852/18th-brumaire/. 